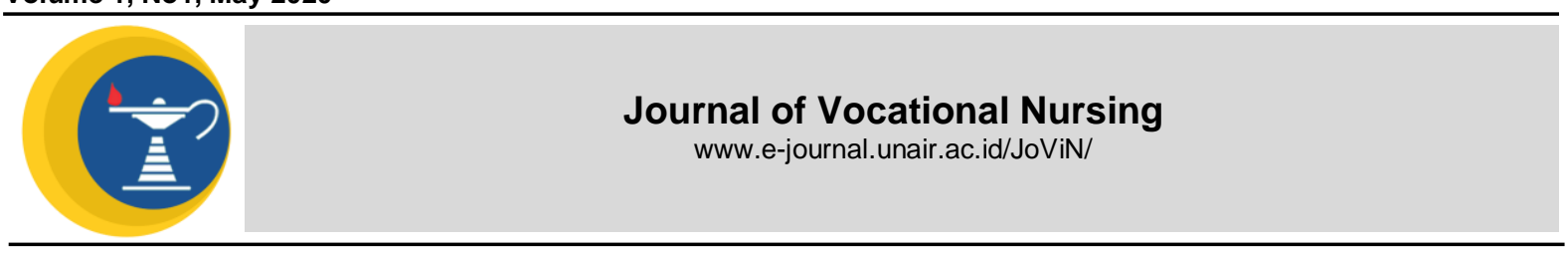

\title{
DESCRIPTION OF ELDERLY KNOWLEDGE ABOUT ELDERLY POSYANDU IN TUMENGGUNG BARU TUMENGGUNGAN VILLAGE, LAMONGAN DISTRICT
}

Ali Sairozi ${ }^{1}$ and Rohmad Nur Hariyanto ${ }^{2}$

DIII Nursing Study Program, Departement of Health, Faculty of Vocational Studies, Universitas Airlangga

\section{A B STRACT}

Introduction: Advanced age is a natural process that cannot be avoided, meaning that aging is a natural rule. The process of aging is caused by biological factors which consist of 3 phases, namely progressive phase, stable phase and regrefif phase. In the anatomic structure the process of aging is seen as a deterioration in the cell. From the initial survey of 25 elderly in Tumenggung, Lamongan Subdistrict, Lamongan Regency, there were problems regarding the decline of Tumenggung elderly Posyandu visits in 2010. The purpose of this study was to identify the description of knowledge about the elderly posyandu in Tumenggung Baru, Lamongan District, Lamongan Regency.

Methods: This study used a descriptive design, with a population of 25 people and a sample of 30 people. Sampling used is total sampling. Data collection with questionnaire sheets, data processing techniques used are Coding, Scoring, and Tabulating techniques, Scoring, then adjusted in tabulation and narration.

Results: From the results of the study showed that most (72\%) of the elderly had good knowledge about the elderly posyandu and a small percentage (12\%) had moderate knowledge and 4 elderly (16\%) had moderate knowledge.

Conclusion: The conclusion of the study is that most of the elderly at the Posyandu in the old Tumenggung elderly district of Lamongan are wellinformed, so that health workers can increase the motivation of the elderly.
ARTICLE INFO

Recived 12 December 2019

Accepted 30 April 2020

Online 29 May 2020

${ }^{*}$ Correspondence:

Ali Sairozi

*Email:

ali.sairozi@vokasi.unair.ac.id

Keywords:

Elderly, Elderly Posyandu,

Knowledge

\section{INTRODUCTION}

The world of health in this era is getting more advanced, supported by health technology that is getting stronger life expectancy is increasing (Anderson, 2007). The high life expectancy indicates that the level of public health is quite good and this is also the government's success in supporting health in this country. Success and happiness due to the increase in life expectancy, on the other hand will leave a problem that we must face. The number of elderly is quite high because the increased life expectancy makes it a problem that we must face together (Nugroho, 2010).

Aging is an unavoidable consequence. Although the aging process is large and is something normal, but in reality this process is more of a burden on others than other processes that occur. This as a whole cannot be avoided by some people who feel more suffering because of the influence of aging than other influences (Watson, 2003).

Elderly Posyandu is a new breakthrough in efforts to maintain and improve elderly health. Elderly Posyandu is a form of health services sourced by the community, assisted by a number of health workers in the region, who will assist the elderly more in health services.

Elderly Posyandu will provide basic health services such as promotive, preventive and early treatment. Elderly Posyandu is an integrated service post for the elderly, which is driven by the community and is a place where the elderly can get health services and services in other fields that aim to make the elderly people healthy, happy, independent and productive. This means that the elderly is a form 
of community participation in elderly health efforts (Ministry of Health, 2010). Elderly Posyandu is one of the efforts to provide health education (HE) to the elderly and foster the active role of the elderly as well as officers and cooperation between agencies. With the holding of the posyandu for the elderly, it is expected that elderly health will be maintained and more improved, so that the elderly will not easily fall ill.

In East Java in 2010 there were 1,156 elderly posyandu, and those that were running around 854 posyandu for the elderly. In Lamongan District 2010 there were about 95 posyandudanyaqng for the elderly, about 25 Posyandu, which were supported by 277 Posyandu cadres, with a target of around 138,863 elderly. The elderly posyandu working area in Tumenggung, LamonganBaru Subdistrict began running in 2008 to 2010, running for approximately 2 years.

In the initial survey on February 25, 2010 at the new Tumenggung Elderly Posyandu, LamonganSubdistrict had an age of 25 people, out of which there were 25 elderly Posyandu in the initial survey on 25 February 2010. whereas on May 19, 2010 the elderly who participated in the elderly posyandu experienced a decrease of 13 elderly. On February 25, 2010 in the new Tumenggung Village, Lamongan, the researcher also gave questions to 25 elderly people, namely to find out the knowledge of the elderly about Poyandu Elderly, the questions amounted to 10 questions.

From the data above shows a decrease in elderly posyandu visits. Many factors influence the decrease in the number of elderly visits at the elderly posyandu, including: knowledge, education, motivation, customs, family roles, officer roles.

Knowledge is the result of knowing and this happens after people do sensing a particular object. Sensing occurs through the five human senses, namely the senses of sight, hearing, smell, taste and touch. Most human knowledge is obtained through the eyes and ears. Knowledge or cognitive is a dominant that is very important in shaping one's actions or inverted behavior (SoekidjoNotoatmodjo, 2012). With good knowledge the family will easily receive information about the knowledge of the elderly and the willingness of the elderly to take part in the elderly posyandu activities, so they will be more cooperative and participate in the activities carried out in the recovery efforts of the elderly and participate in the posyandu. Likewise, the knowledge of the elderly family that is low or lacking results in the lack of active role of the elderly in the elderly posyandu activities.

Education is all efforts that are planned to influence individuals, groups or communities so that the elderly family does what is expected by the perpetrators of education (SoekidjoNotoatmojo, 2012). Education in the past obtained by the elderly family has an influence on the lives of the elderly today, when health education was provided, the elderly would be able to take care of the health of the elderly, including utilizing the health services in their environment as well as possible. And vice versa if in the past the elderly family had never received education about health, the elderly family at this time also could not take advantage of health services in their area, for families who have elderly.

Motivation is something that underlies a person's behavior, every action and action has a motive. Intrinsic motivation means that something is desirable because someone likes to do it, motivation comes from within the person himself. While extrinsic motivation is that something is done because of external force himself (Monks, 2004). Elderly families who have the motivation to support the elderly to participate in the posyandu activities aim to live healthy and avoid illness, and vice versa the elderly who have no motivation to support the elderly still maintain their health.

Customary customs are something that is usually done for generations in the family (Ahmad, 2006). If the family has good health habits, all family members also have good health habits. If it comes out, if they have problems with their health, they then ask for help from the health service unit, so when there is a posyandu, the elderly family will encourage the elderly in the family to attend the posyandu for the elderly.

The role of the family shows some behavior that is more or less homogeneous which is identified and expected normatively from someone or in a particular system. The role of the family is based on the precryption and expectation of roles that explain what the individual must do in certain situations in order to meet their own expectations or the expectations of others regarding the role of results (Friedman, 1998). The role of the family has a huge influence on the attitudes, actions and health behaviors of family members, including the participation of the elderly in the elderly posyandu. A good family will provide support and encouragement to elderly family members to join the Posyandu for the elderly.

The role of health workers is to provide counseling to the elderly and their families about the health of the elderly as well as the 
elderly Posyandu as well as continuous information from health workers regarding elderly health.

From the description above, the researcher concluded that many factors influenced visits to the elderly posyandu, one of which was knowledge, besides that it could also provide counseling to the elderly and their families about the health of the elderly.

\section{MATERIALS AND METHODS}

This type of research is descriptive using the total sampling method. The population of this study was the elderly in the new Tumenggung Posyandu, the village of Tumenggungan, Subdistrict of Lamongan, while the sample was all the elderly in the new Posenggandu Tumenggung,Kelurahan Tumenggungan Kecongan Lamongan in February 2010 that met the inclusion criteria with a sample of 25 people. The variable is the Overview of Elderly Knowledge About Elderly Posyandu. Data collection using questionnaire sheets and data processing using editing, coding, tabulation and percentage.

\section{RESULTS}

Table 1 Distribution of Respondents by age at Tumenggung Baru Elderly Posyandu in Lamongan District in 2010.

\begin{tabular}{cccc}
\hline No & Age & Frequency & Percentage \\
\hline 1 & $60-65$ years & 1 & 4 \\
2 & $66-75$ years & 14 & 56 \\
3 & $>75$ years & 10 & 40 \\
\hline & Total & 25 & 100 \\
\hline
\end{tabular}

Shows the majority of respondents in the Lamongan Elderly Posyandu in 20102010 aged 66-75 years as many as 14 or $56 \%$ of respondents. A small percentage of respondents in the Tumenggung Baru Elderly Posyandu in 2010 were $60-65$ years old with 1 or $4 \%$ of respondents.

Table 2 Distribution of Respondents based on Education at the Lamongan Elderly Posyandu in 2010.

\begin{tabular}{cccc}
\hline No & Education & Frequency & Percentage \\
\hline 1 & Grammar school & 18 & 72 \\
2 & Elementary school & 6 & 24 \\
3 & Junior High School & 1 & 4 \\
\hline & Total & 25 & 100
\end{tabular}

Shows that the majority of respondents in the Lamongan Elderly Posyandu in 2010 had a public school education of 18 respondents or $72 \%$ of respondents. While a small proportion of respondents in the Tumenggung Baru Elderly Posyandu have high school education as much as 1 respondent or $4 \%$.

Table 3 Distribution of Respondents by Job in the Lamongan Elderly Posyandu in 2010.

\begin{tabular}{|c|c|c|c|}
\hline No & Job & Frequency & Percentage \\
\hline 1 & Farmer & 19 & 76 \\
\hline 2 & Entrepreneur & 3 & 12 \\
\hline 3 & Job less & 3 & 12 \\
\hline \multicolumn{2}{|c|}{ Total } & 25 & 100 \\
\hline
\end{tabular}

Shows the majority of respondents in the Lamongan Elderly Posyandu in 2010 worked as farmers as many as 19 respondents or $76 \%$ and a small proportion of respondents from the Posyandu Lansia Tumenggung Baru were self-employed and did not work as many as 3 respondents or $12 \%$.

Table 4 Distribution of Respondents by Gender in the Lamongan Elderly Posyandu in 2010.

\begin{tabular}{|c|c|c|c|}
\hline No & Gender & Frequency & Percentage \\
\hline 1 & Male & 8 & 32 \\
\hline 2 & Famale & 17 & 68 \\
\hline \multicolumn{2}{|c|}{ Total } & 25 & 100 \\
\hline
\end{tabular}


Shows that the majority of of respondents in the Lamongan Elderly Posyandu in 2010 were female as many as 17 respondents or $68 \%$ and a small percentage of respondents from the Tumenggung Baru Elderly Posyandu were as many as 8 respondents or $32 \%$.

Table 5 Distribution of of Respondents Based on Elderly Knowledge AboutLamongan Elderly Posyandu in 2010.

\begin{tabular}{|c|c|c|c|}
\hline No & Knowledge & Frequency & Percentage \\
\hline 1 & Good & 18 & 72 \\
\hline 2 & Enough & 3 & 12 \\
\hline 3 & Less & 4 & 16 \\
\hline \multicolumn{2}{|c|}{ Total } & 25 & 100 \\
\hline
\end{tabular}

Shows that the majority of respondents had good knowledge of 18 respondents or $72 \%$. While a proportion of respondents have moderate knowledge, namely 3 respondents or $12 \%$.

\section{DISCUSSION}

Based on table 5 shows that most of the respondents were well-informed about the Elderly Posyandu. The knowledge in question is the Elderly able to answer the questions well given by the researcher. With good knowledge it will have a positive impact in seeking treatment and care and vice versa if the knowledge of the elderly is lacking it will have a negative impact. This situation can be caused by several things including, based on age, education, work, interests, experience, which are related to knowledge of the elderly.

This is in accordance with the opinion of Wahid lqbal Mubarak (2009) which states that the factors that influence knowledge are education, work, interests, experience, culture and information. Researchers agree about Wahid lqbal Mubarak's (2012) statement that knowledge is influenced by education, work, interests, experience, culture and information. All of these factors will have a positive effect if these factors are good and vice versa if these factors will not have a negative impact on elderly knowledge.

Most of the elderly at Tumyung Baru Elderly Posyandu in Lamongan District in 2010 were $66-75$ years old, 13 elderly or $52 \%$. So, in the Tumyung Baru Elderly Posyandu in Lamongan District in 2010 most of them were middle aged people. This is in accordance with Watson (2003) statement of elderly people aged 66-75 who are middle aged. According to researchers, most of the elderly at Tumyung Baru Elderly Posyandu are middle aged. So, the researchers agreed on the opinions expressed by Watson (2003), but of the 25 elderly 13 elderly were middle aged people, 11 very elderly elderly and 1 young elderly elderly.

From the results of the study, almost the majority of the elderly were educated by the people and a small number of junior high schools. Even though they were from public schools and junior high schools, the elderly continued to actively participate in the posyandu activities for the elderly and were able to answer questions given by the officers. With this background and activity, counseling from health workers is easy and can be applied in the posyandu for the elderly.

This is in accordance with the opinion of Soekidjo Notoatmodjo (2012) which states that the higher the education or experience of a person, the easier it is to receive information so that more knowledge is owned and eventually used as knowledge formation, whereas less experience education can hinder someone's knowledge of new values introduced. It is true that education or experience is high so it will be easy to receive information and good knowledge, but it is seen from the fact that the opinion is not right. This can be seen from the educational background of the elderly at Posyandu Tumenggung Baru, who were educated in public schools and public school education could be said to be low education.

Customary customs are something that is usually done for generations in the community. If the community has good health habits, it will also reflect good socio-cultural life. From this description it can be concluded that socio-culture is a factor that also influences the knowledge of the elderly.

\section{CONCLUSION}

From the results of the research and discussion above, it can be concluded that the majority of respondents have good knowledge about the Elderly Posyandu.

\section{REFERENCES}

Anderson, Elizabet T, (2007). Buku Ajar Keperawatan Komunitas Teori dan Praktik, EGC : Jakarta.

Arikunto, Suharsimi. (2014). Prosedur Penelitian Suatu Pendekatan Praktik. Jakarta : Rineka Cipta. 


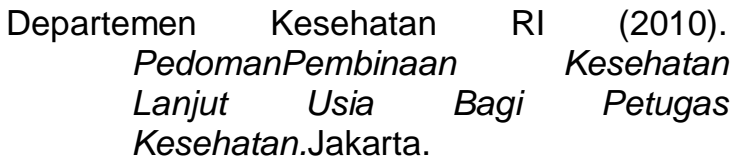

Friedman, (1998). Gerontologi Kesehatan, EGC : Jakarta.

Mubarok, Wahid lqbal. (2006). Pengantar Keperawatan Komunitas ., Sagung Seto: Jakarta

Mubarok, Wahit Iqbal \&NurulChayatin, (2009). Pengantar dan Teori IImu komunitas Buku 1, Jakarta : Salemba Jakarta.

Nugroho, W (2010). Keperawatan Gerontik dan Geriatrik Edisi ketiga, EGC : Jakarta
Nursalam, (2011). Konsep Penerapan Penelitian dan Metode Penelitian IImu Keperawatan, Jakarta : Salemba Jakarta

Notoatmojo, Soekidjo. (2012). Promosi Kesehatan dan Perilaku Kesehatan.Rineka Cipta: Jakarta.

Notoatmojo, Soekidjo. (2007). Promosi Kesehatan dan IImu Prilaku, Jakarta : Rineka Cipta.

Price, Silvia Anderson, (2015). Patofisiologi Konsep : Konsep Klinis proses-proses penyakit, EGC : Jakarta.

Stanly, Micklydan Patricia GautleltBeare, (2006).Buku Ajar Keperawatan Gerontik,EGC : Jakarata. 